Армирование ледового покрова может увеличить срок службы ледовой переправы до 20 дней.

Исходя из вышесказанного, можно сделать вывод, о том, что армирование ледового покрова пайкеритом является наиболее эффективным способом возведении ледовых переправ, позволяет увеличить несущую способность до 20 и более тонн и повысить грузооборот (более 100 авт./сут) переправы.

Список литературы:

1. Проект «Хаббакук» http://alternathistory.com/proekt-khabbakuk-samyi-moshchnyivoennyi-korabl-v-istorii

2. http://stroysklad.com/post/62/pajjkerit-ljod-opilki

3. Песчанский И.С. Ледоведение и ледотехника Издание 2-е / И.С. Песчанкий, Гидрометеорологическое изд-тво, Ленинград, 1967.

\title{
Построение систем линеаментов по модулю плотности градиента рельефа
}

Тусикова С.A., аспирантка, Институт тектоники и геофизики ДВО РАН, 2. Хабаровск

E-mail: svetabon@list.ru

\section{Научный руководитель: о.г.-м.н., профессор Трофименко С.В.}

Данное исследование было проведено на основе анализа космических снимков в программной среде LESSA с различным разрешением. Основу предлагаемого анализа составляют линейные элементы изображения. Программа автоматически выявляет их и определяет направление. В полутоновом изображении штрихи - это границы однородных областей и/или линии, которые должны быть достаточно длинные и прямые. В цифровых моделях рельефа определяются и анализируются оси долин и хребтов.

Для анализа штрихов использовано два различных подхода - статистический анализ и построение протяжённых линеаментов. В первом случае, оценивается расположение штрихов каждого направления на изучаемой площади. Соотношение штрихов разного направления в заданной окрестности отображается розой-диаграммой.

По результатам измерений в скользящем окне строятся псевдоцветные изображения («поля»), которые показывают плотность штрихов различного направления, и такие характеристики роз-диаграмм, как вытянутость, крестообразность, отличие от окружающих и др. Эти изображения изучаются и интерпретируются интерактивно.

Результаты статистического анализа штрихов представляются и в графическом виде. Данные о преобладающих направлениях текстуры LESSA представляет и в виде сети линий вытянутости [4].

Линеаменты и сейсмичность Алданского щита и Приамурья. Для дальнейшего изложения результатов данного исследования важно отметить, что при моделировании пространственной структуры сейсмичности принимается априорное 
положение, основанное на допущении, что землетрясения, приуроченные к определённым структурам, являются следствием длительного развития самих структур. Следовательно, области эпицентров сильных землетрясений и рассеянной сейсмичности должны пространственно укладываться в активные деформационные структуры. Отсюда возникает задача по определению пространственного положения данных структур, контролирующих сейсмический процесс.

Предварительные данные о геометрических построениях линеаментных структур Алдано-Станового мегаблока методами статистического анализа пространственного распределения геофизических полей изложены в работах $[5,6,7]$. Первые результаты моделирования показали, что эпицентры землетрясений по площади распределены не равномерно и представлены полями очаговой и рассеянной сейсмичности $[1,2]$. Для центральной части северного сегмента Амурской микроплиты характерно изменение азимутов осевых линий плотности эпицентров землетрясений [10, 17] (рис. 1).

Сравнительный анализ пространственного распределения эпицентров землетрясений и разработанной модели грави- и магнитолинеаментов АлданоСтанового мегаблока в работах [13-16] показал, что в систему линеаментов с азимутами (40-310 $)^{\circ}$ укладывается структура сейсмического поля, а к узлам, образованным пересечением линеаментов данной системы, либо к её осевым линиям, тяготеют все эпицентры сильных землетрясений.

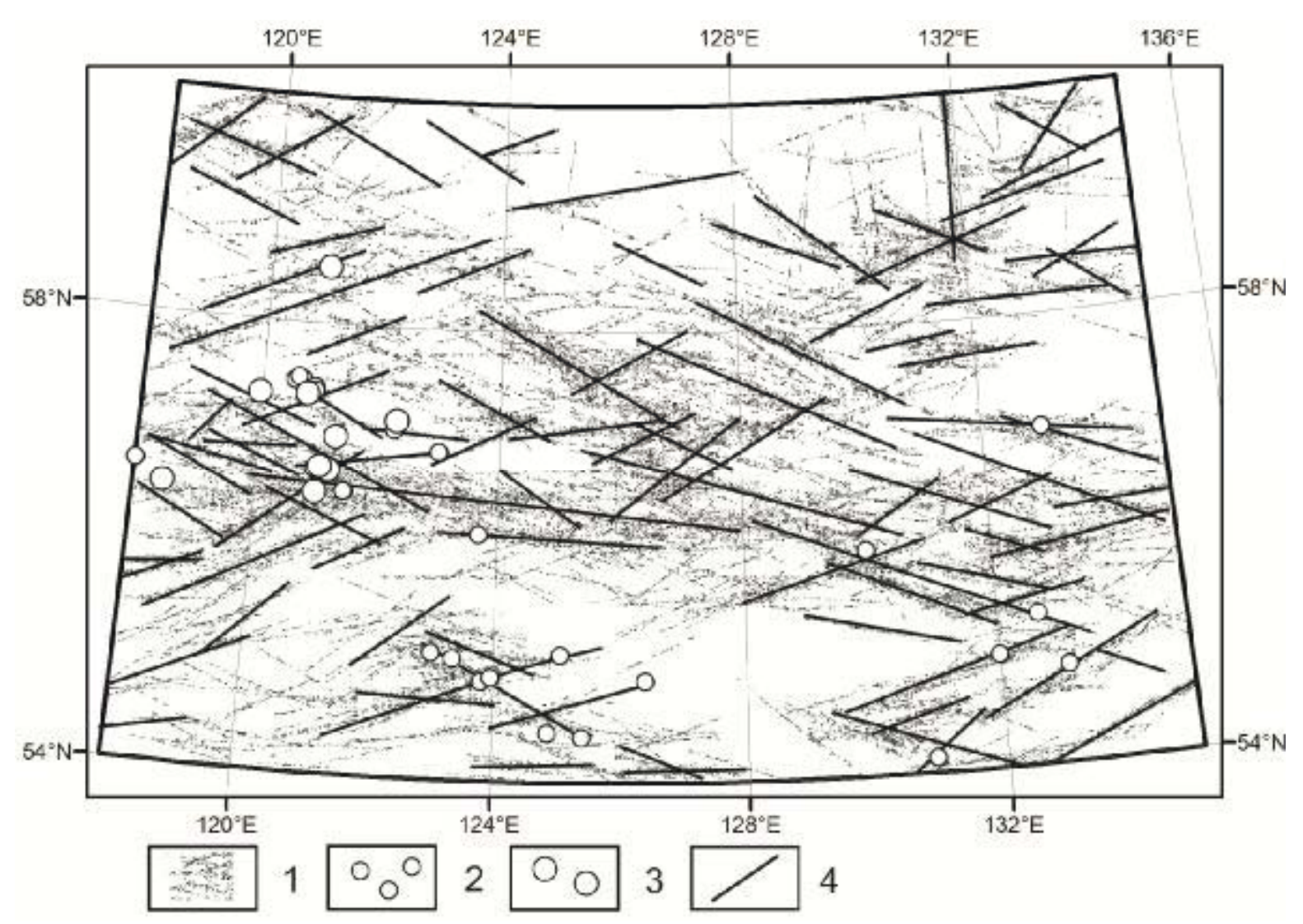

Рис. 1. Карта плотности модуля градиента рельефа (по [11] с дополнениями)

Обозначения: 1 - индикаторы модуля градиента площади исследований; 2 - эпицентры землетрясений с магнитудой от $\mathrm{M} \leq 5 ; 3$ - эпицентры землетрясений с магнитудой от $\mathrm{M}>5 ; 4$ тополинеаменты 
Для выделения линейных структур наиболее эффективным инструментом является модуль градиента, т.к. в зонах разрывных нарушений почти всегда присутствуют пространственно вытянутые участки с близкими значениями градиентов. Кроме того, в любой точке экстремума значение модуля градиента близко к нулю, что позволяет в результате отчётливо выделять долины и хребты в виде протяжённых линейных объектов [3].

Для сопоставления пространственного распределения поля сейсмичности с модельными факторами в работах [13-16] рассматриваются два признака:

1) сопоставление рассеянного поля сейсмичности и очаговых зон с положением и структурой грави- и магнитолинеаментов;

2) рассмотрение модели тополинеаментов по материалам цифровых моделей рельефа в сопоставлении с эпицентрами сильных землетрясений.

Также в данных работах рассчитанная структура тополинеаментов показала полную идентичность структуре грави-магнитолинеаментов как по азимутам (40-310을 так и по доменной структуре. Все сильные землетрясения восточного фланга Алданского щита приурочены либо к зонам сгущения индикаторов модуля градиента, либо к отдельным тополинеаментным структурам.

Таким образом, полученный результат позволяет предположить, что система линеаментов в азимутах (40-310 ${ }^{\circ}$ может быть ассоциирована с зонами активного деформирования земной коры в настоящее время и контролирует сейсмический процесс в пределах зоны конвергентного взаимодействия Амурской коровой и Евразийской литосферной плит. Результаты построений по изложенной методике показаны на рис.1, на котором вынесены линейные структуры по пространственному распределению плотности модуля градиента.

Выводы. Ранее установлено, что сейсмический процесс Алдано-Станового блока контролируется линеаментами северо-восточной и северо-западной ориентировок (рис.1), что соответствует раннее полученным результатам для западного блока Алданского щита $[9,12,8]$. В результате сопоставления диагональной системы аномалий геофизических полей с пространственным распределением поля современной сейсмичности и эпицентрами сильных землетрясений в западной части АлданоСтанового блока и тополинеаментов на северо-восточной окраине Амурской плиты можно сделать предположение, что диагональная система линеаментов отражает зоны тектонических деформаций и контролирует эпицентральные поля современной сейсмичности.

\section{Список литературы:}

1. Имаев В.С., Имаева Л.П., Козьмин Б.М. и др. Буферные сейсмогенные структуры между Евразиатской и Амурской литосферными плитами на юге Сибири // Тихоокеанская геология. 2008. Т. 22, № 6. С. 55-61.

2. Имаева Л.П., Имаев В.С., Козьмин Б.М. Сейсмогеодинамика АлданоСтанового блока // Тихоокеанская геология. 2012. Т. 31. № 1. С. 5-17.

3. Короновский Н. В., Брянцева Г. В., Гончаров М. А., Наймарк А. А., Копаев А. В. Линеаменты, планетарная трещиноватость и регматическая сеть: суть явлений и терминология // Геотектоника. 2014. № 2. С. 75-88.

4. Линеаментный анализ [Электронный ресурс]: алгоритм. - Режим доступа: http://www.lineament.ru/algor.htm. - (Дата обращения: 19.01.2017) 
5. Статива А.С., Трофименко С.В., Гриб Н.Н. Анализ существующих представлений о тектонике Алданского щита // Горный информационно-аналитический бюллетень (научно-технический журнал). 2006. Т. 17. № 3. С. 167-189.

6. Статива А.С., Трофименко С.В., Имаев В.С. Пространственное распределение индикаторов систем разломов Алданского щита // Горный информационноаналитический бюллетень (научно-технический журнал). 2006. Т. 17. № 4. С. 188-197.

7. Трофименко С.В. Геофизические поля и сейсмичность Южной Якутии // Горный информационно-аналитический бюллетень (научно-технический журнал). 2007. Т. 17. № 1. С. 188-196.

8. Трофименко С.В. Закономерные изменения параметров сейсмического процесса Олекмо-Становой зоны (ОС3) // Горный информационно-аналитический бюллетень (научно-технический журнал). 2007. Т. 17. № 1. С. 196-203.

9. Трофименко С.В. Оценка энергии возможного землетрясения ОлекмоСтановой зоны // Горный информационно-аналитический бюллетень (научнотехнический журнал). 2006. Т. 17. № 3. С. 149-155.

10. Трофименко С.В. Проявление землетрясений на фоне стационарного сейсмического процесса Олекмо-Становой зоны (ОС3) // Горный информационноаналитический бюллетень (научно-технический журнал). 2007. Т. 17. № 1. С. 208-213.

11. Трофименко С.В., Гильманова Г.3., Никитин В.М., Колодезников Линеаментный анализ пространственного поля сейсмичности северного сегмента Амурской микроплиты // Наука и образование.- №1 (81), 2016. С.7-13.

12. Трофименко С.В., Гриб Н.Н. О возможности прогноза эпицентра сильного землетрясения по структуре сейсмического поля Олекмо-Становой зоны // Горный информационно-аналитический бюллетень (научно-технический журнал). 2006. Т. 17. № 3. С. 189-193.

13. Тусикова С.А. Методы и технологии линеаментного анализа геофизических полей. На примере Алдано-Станового блока. // Эволюция научного знания: сборник статей международной научной конференции / Россия, Москва, 28-29 ноября 2016 г. [Электронный ресурс] / под ред. проф. А.А. Алпатова, Р.В. Овчаровой. М.: РусАльянс Сова, 2016. С. 98-105.

14. Тусикова С.А. Системы геофизических и топографических линеаментов Алданского щита и северо-восточного сегмента Амурской микроплиты //Эволюция научного знания: сборник статей международной научной конференции /Россия, Москва, 28-29 ноября 2016 г. [Электронный ресурс] / под ред. проф. А.А. Алпатова, Р.В. Овчаровой. М.: РусАльянс Сова, 2016. С. 106-114.

15. Тусикова С.А., Колягина О.А. Линейные индикаторы речной сети восточного фланга Алдано-Станового блока. Обзор работ и первые результаты // Инновационная парадигма устойчивого развития науки. Теория и практика. / Сборник научных статей международной научно-практической конференции Санкт-Петербургского Центра Системного Анализа 15-16 декабря 2016 г. СПб.: Изд-во: КультИнформПресс. 2016. С. 20-23. http://elibrary.ru/item.asp?id=27478567.

16. Тусикова С.А., Колягина О.А. Линейные элементы геофизических полей восточной части Алдано-Станового блока. Обзор работ и первые результаты //Инновационная парадигма устойчивого развития науки. Теория и практика. /Сборник научных статей международной научно-практической конференции СанктПетербургского Центра Системного Анализа 15-16 декабря 2016 г. СПб.: Издво: КультИнформПресс. 2016. C.23-26. http://elibrary.ru/item.asp?id=27478567. 
17. Ovsyuchenko, A.N., Trofimenko, S.V., Marakhanov, A.V. et. al. Detailed Geological-Geophysical Studies of Active Fault Zones and the Seismic Hazard in the South Yakutia Region. Russian Journal of Pacific Geology. 2009. Vol. 3(4). P. 356-373. DOI: 10.1134/S1819714009040046.

\title{
Построение систем линеаментов геофизических полей восточного фланга
} Алданского щита

\author{
Тусикова С.А., аспирантка, \\ Институт тектоники и геофизики ДВО РАН, \\ 2. Хабаровск \\ E-mail: svetabon@list.ru
}

Научный руководитель: д.2.-м.н., профессор Трофименко С.В.

Сформулированная американским исследователем Уильямом Хоббсом [18] методика анализа рельефа в виде линейных структур успешно развивалась второй половине XIX века [17] для различных регионов Земли.

Начиная с 60-х гг. XX века, ряд авторов [3] разрабатывали методику дешифрирования рельефа земной поверхности и материалов дистанционного исследования Земли с целью выявления зон скрытых разломов фундамента, тектонических блоков и магматических очаговых структур, контролирующих размещение эндогенного оруденения. В дальнейшем сферу линеаментного анализа были включены и геофизические материалы (карты гравиметрических и магнитометрических съёмок), представленные в виде различных трансформаций аномальных геофизических полей [19].

Линеаментный анализ широко используется при прогнозе месторождений полезных ископаемых, прогнозе землетрясений, выявлении мест развития коллювиальных отложений и оползневых участков, прогнозе путей миграции подземных вод, оценке стабильности блоков геологической среды при проектировании и строительстве сооружений военного, гражданского и промышленного назначения, выборе конкретных вариантов размещения социально и экологически значимых техногенных объектов: линейного транспорта (ЛЭП, газо- и нефтепроводов), плотин, мостов, туннелей, хранилищ вредных отходов, ядерного топлива и др. [1, 17].

В геологической практике выявления и изучения линеаментов используются различные методы: прямые и косвенные, качественные и количественные [8, 10]. Прямые методы выявления и изучения линеаментов связаны с визуальным поиском, выделением и трассированием протяжённых прямолинейных, пересекающих площадь исследования, элементов геофизических полей. Косвенные методы связаны в основном с поиском, выделением и трассированием линеаментов по данным о пространственном размещении различных параметров рельефа [7, 11]. Прямые и косвенные методы поиска, выделения и изучения линеаментов образуют вместе комплекс качественных методов поиска и выявления линеаментов, основы которых заложены в фундаментальных работах $[18,19]$. 